\title{
Imagination and Scenic Expression in Performance Art
}

\author{
Anca Iorga \\ Faculty of Physical Education and Sports, Spiru Haret University, Bucharest, Romania \\ Email: iorga.anca@gmail.com
}

How to cite this paper: Iorga, A. (2019). Imagination and Scenic Expression in Performance Art. Psychology, 10, 1116-1124. https://doi.org/10.4236/psych.2019.108072

Received: May 21, 2019

Accepted: June 25, 2019

Published: June 28, 2019

Copyright $\odot 2019$ by author(s) and Scientific Research Publishing Inc. This work is licensed under the Creative Commons Attribution International License (CC BY 4.0).

http://creativecommons.org/licenses/by/4.0/

\begin{abstract}
This paper aims at revealing the relationship between imagination and the scenic expression of the student actors, as a relevant sign of the talent for performance art. We took into account two indicators which we found essential for the scenic talent: an internal indicator which involves the processing of the role-related data largely on the basis of creative imagination, and an external one which covers the embodiment of the character by way of the system of expression means. If improvisation, as a creation method, helps the student actor capitalise on their creative abilities, we can determine, following the psychological mechanism of improvisation, the relationship between imagination and the scenic expression, and the extent to which scenic talent may be expressed by improvisation. To this end, we started from turning some classical improvisation exercises used in the training sessions of the student actors, into psychological improvisational models applied as a natural experiment. This approach resulted in positive correlations between the indicator being assessed and the artistic performances of the student actors.
\end{abstract}

\section{Keywords}

Imagination, Improvisation, Capacity to Transpose, Capacity of Expression

\section{Introduction}

Creativity in the art world is considered an expression of the personality, which involves long time training and great effort from a performer in order for them to express themselves in the work of art. Creativity assumes not only the existence of some abilities, but a general predisposition of the personality toward the original, the novel, as well as the favourable organisation and correlation of the mental processes of the performer (Popescu, 2004). In order to be capable to embody a character, the actor undergoes double effort-a mental effort involv- 
ing stimulation and engagement of the cognitive and affective processes, and a physical effort resulting in enhanced metabolism due to muscular activity. The actor must perceive and estimate the intensity of the aforementioned types of effort (mental and physical) to truly become expressive and competitive (Toivane \& Kaasinen, 2016).

In acting, we use creative expression; it translates into mimics and gestures, on the one hand, and into verbal communication, on the other. Logically speaking, creativity leads to the appropriate organisation of the information the actor has to assimilate but also to the development of new structures and ideas (Zlate, 1999).

This paper aims at revealing the relationship between imagination and the scenic expression of the student actors, as a relevant sign of the talent for performance art.

We took into account two indicators that we consider to be essential for the scenic talent: an internal indicator which involves the processing of the role-related data largely on the basis of creative imagination, and an external one which covers the embodiment of the character by way of the system of expression means. These two indicators may be assessed separately as well, but observing the psychological structure of the scenic talent and applying the results obtained in the selection and training of the student actors require addressing them in the context of their natural relationship.

In studying the talent of a performer from a psychological perspective, the relationship between the two abovementioned indicators appears to be an important hypothesis which must be demonstrated experimentally, instead of being accepted as a permanent acquisition. This is due to the great diversity of skills in actors. Therefore, these indicators involve a variety of relationships between different components, different modalities of individual and category expression. Thus, we can say that besides the theoretical justification of the research, there is also a practical motivation related to the embodiment of the character.

The main activity of a performer by which they express their talent is improvisation (Reeve, 2011). Improvisation is an important element in training the student actors and, at the same time, an indispensable procedure in the performer's creative activity, sometimes acting as a form of revitalisation of the performer (Morgenroth, 1987). In performance art improvisation takes two shapes-first, it is a creative act helping the artist act out a story (Stanislavski, 2018) and second, it has an instructional side, being considered a teaching and artistic means used in acting schools (Grotowski, 2009). However, we appreciate that improvisation is the capacity to invent, to anticipate, by means of imagination, the tasks imposed by the role to be played, by exhibiting an appropriate artistic behaviour in accordance with the scenic situation.

If we define improvisation from a psychological standpoint, we can affirm it is a body of spontaneous responses and actions resulting from an experience, which are instantly adapted, structured and performed in relation to the given 
situation (Golu, 2007). In researching the scenic talent, we suppose improvisation must be approached from two perspectives:

- It is a creation act-which reflects the unity between the capacity for imagination and the capacity of expression.

- It is an educational method-it models the teaching and artistic activity, on the one hand, and develops the creative abilities of the actor, on the other.

\section{Methodology}

\subsection{Hypothesis}

If improvisation, as a creation method, helps the student actor capitalise on their creative abilities, we can determine, following the psychological mechanism of improvisation, the relationship between imagination and the scenic expression, and the extent to which scenic talent may be expressed by improvisation.

We need to mention, though, that the improvisational ability of the student actor does not reflect their talent in all its complexity, but an important side of it.

\subsection{Research Participants}

As regards the research participants, we will take into account both the tested subjects and the evaluators.

The study was conducted on a group of ten $2^{\text {nd }}$ year students from the University of Theatre and Film I. L. Caragiale, Bucharest. Therefore, the subjects were at the half of their training path for the desired career $\left(2^{\text {nd }}\right.$ year of study, Cycle I Bologna). The experimental group consisted of the students who scored best on the specialty exams (acting, improvisation and scenic movement), specifically those graded with 8 to 10 on all midterms.

The jury consisted of three members: an acting teacher, a dance and scenic movement teacher and a psychologist. The acting teacher was the academic supervisor of the class of students the tested subjects belonged to, therefore he/she was familiar with all of them. Due to the over 20 years' standing as a teacher, his/her opinion was considered when forming the experimental group of students. We included the dance teacher because onstage nonverbal communication requires a movement expert's eye. As for the psychologist who participated in the research, not only that he/she majored in art psychology but graduated from both Faculty of Psychology and Drama School. We have chosen this composition of the jury in our attempt to form a competent team of evaluators who can cover a wider spectrum of aspects both from the field of arts and from the psychology area.

\subsection{Research Method}

We started from processing and turning some classical improvisation exercises (Aron, 1999) used in the training sessions of the student actors, into psychological improvisational models applied as a natural experiment. These exercises may be used as situational tests (Zlate, 2000). 
The improvisation exercise chosen was presenting some Romanian proverbs selected according to the possibility of the internal elaboration of the scenic task and of its communication to the audience by using diverse means of expression. Twenty proverbs were chosen (Botezatu \& Frincu, 2001). They were written on slips of paper that were put into a bowl (see Table 1).

Each student would draw a slip of paper bearing a proverb. They were given enough time to think the manner in which they would perform the task (with or without partners, using objects or not, with or without stage clothes, and the like), after which they would start performing (see Table 2).

By choosing this method, we have tried to provide the conditions for the internal elaboration of the task (the mental processing of the proverb, the capacity of the student actor to transpose themselves) and for the embodiment of the role (using the expression means to communicate the improvisation topic). To exemplify the method used, we will describe a few improvisation topics and the way in which the student actors chose to act them out:

Table 1. Proverbs.

\begin{tabular}{|c|c|}
\hline No. & Proverb \\
\hline 1. & Water flows, rocks remain. \\
\hline 2. & Charity begins at home. \\
\hline 3. & The early bird catches the worm. \\
\hline 4. & The apple doesn't fall far from the tree. \\
\hline 5. & The young pig grunts like the old sow. \\
\hline 6. & Practice makes perfect. \\
\hline 7. & Where two dogs are fighting for a bone, the third runs away with it. \\
\hline 8. & One man's trash is another man's treasure. \\
\hline 9. & A small leak will sink a great ship. \\
\hline 10. & When the cat's away, the mice will play. \\
\hline 11. & It's easy to be wise after the event. \\
\hline 12. & Keep your friends close and your enemies closer. \\
\hline 13. & A thief passes for a gentleman when stealing has made him rich. \\
\hline 14. & Barking dogs seldom bite. \\
\hline 15. & Necessity is the mother of invention. \\
\hline 16. & A chain is only as strong as its weakest link. \\
\hline 17. & A man's hat in his hand never did him any harm. \\
\hline 18. & Running away is shameful but useful. \\
\hline 19. & A stitch in time saves nine. \\
\hline 20. & Better late than never. \\
\hline
\end{tabular}


Table 2. Scores recorded by the subjects.

\begin{tabular}{ccccc}
\hline & $\begin{array}{c}\text { Subjects' } \\
\text { initials }\end{array}$ & $\begin{array}{c}\text { Number of slip } \\
\text { of paper drawn }\end{array}$ & $\begin{array}{c}\text { Arithmetic mean for } \\
\text { imagination }\end{array}$ & $\begin{array}{c}\text { Arithmetic mean for } \\
\text { expressiveness }\end{array}$ \\
\hline 1. & A. M. M. & 6 & 7.66 & 8.00 \\
2. & B. C. & 5 & 9.66 & 9.00 \\
3. & C. I. V. & 1 & 9.66 & 9.33 \\
4. & G. L. M. & 12 & 8.66 & 8.66 \\
5. & H. A. & 9 & 9.33 & 9.00 \\
6. & I. D. & 17 & 7.00 & 7.33 \\
7. & R. M. & 13 & 8.33 & 8.66 \\
8. & S. O. F. & 11 & 7.66 & 8.00 \\
9. & S. D. & 20 & 6.00 & 6.66 \\
10. & P. G. & 10 & 8.66 & 8.33 \\
\hline
\end{tabular}

- Water flows, rocks remain (Botezatu \& Frincu, 2001) - The student used all 9 of their colleagues, placing them diagonally in the performance space in different positions (sitting, squatting, standing, and the like), then went through them from back to front holding a bucket full of water. Explanation of the subject: I have depicted the situation in a plastic and as simple as possible manner. The arithmetic mean of the marks awarded for imagination was 9.66, while the arithmetic mean reflecting the subject's expressiveness was 9.33 .

- A small leak will sink a great ship (Botezatu \& Frincu, 2001)-The student used 6 colleagues in his/her attempt to portray the ship: 4 students forming a square, holding hands represented the ship; they were carrying their fifth colleague-who was handling the ship-on their shoulders, while the sixth student was ahead of them taking jumping steps, embodying a horse at the canter. The student who initiated the action was sitting in a squatting position in the middle of the performance space. The structure of bodies representing the ship crossed the space from right to left. When reaching the middle of the performance space, the squatting student started rolling over, breaking down the body construction. Explanation of the subject: I have depicted the proverb in a suggestive and very simple manner and I believe my approach can be easily comprehended. The subject's imagination endeavour resulted in a 9.33 arithmetic mean, while expressiveness was graded with 9.00 .

- A man's hat in his hand never did him any harm (Botezatu \& Frincu, 2001)The student used all 9 colleagues, arranging them in a line; the first three people had their heads bent down, the next three kept their heads slightly tilted, while the remaining three adopted an upright body posture. The subject was standing in the front side of the performance space holding a broomstick for a sword. The 9 students were moving toward their colleague who was giving them verbal directions, keeping large spaces between them. 
When in front of the subject, they got hit by them with the broomstick. Those six who maintained eye contact with the student holding the sword fell on the floor. The three students keeping their heads bent down remained standing. Explanation of the subject: I have chosen the simplest and easiest to explain solution. The arithmetic mean of the imagination marks was 7.00 , while the expressiveness arithmetic mean was 7.33.

Evaluation covered the identification of the scenic task and the capacity of the student actors to convey the intended message to the audience, and resulted in marks from 1 to 10 . Based on the procedures of identifying the task given and evaluating the subjects' performance, the student actors were ranked in point of imagination, on the one hand, and of expressiveness, on the other.

\section{Results and Discussions}

The arithmetic mean for the entire group of students for imagination indicator was 8.00, while the arithmetic mean for expressiveness indicator was 8.66. This yielded a final average of 8.33 . The relatively high averages obtained by the students show that the level of difficulty of the scenic task was not extremely high and that training the improvisational abilities for the last almost two years of acting school helped them perform their tasks rapidly and appropriately.

It stands to reason that there is a connection between the evaluators identifying the improvisation topic and assessing the subject's performance. Obviously, an unidentified topic results in a low grade. Nevertheless, not every subject presenting an easily recognisable topic is likely to score high.

Following the hypothesis and the results obtained by the student actors, we can state that there is a relationship between imagination and expressiveness reflected in the communication of the improvisation topic to the audience. The statistical analysis of the collected data indicates a high correlation coefficient between these two parameters, namely 0.67 . This shows us that the tested student actors, whether they rank high or low in terms of imagination and expressiveness, present minimal differences between the values recorded for these two parameters. The issue arising is related to the specificity of the relationship between imagination and expressiveness. We have noticed that expressiveness is linked to the affective content of the internal elaborations, which indicates a complex of emotional attitudes of each subject towards the imagined elements (Iorga, 2017). The imagination-expressiveness relationship reveals the scenic talent of the subjects.

The relationship between imagination and expressiveness is the most important prerequisite in performance art. It is the fundamental indicator of the scenic talent and it necessarily involves the organic unity between the capacity to transpose and the capacity of expression (mimics and gestures) (Neacşu, 1971). Nevertheless we must mention that it takes practice for the two factors to coexist, hence this relationship is built on the student actors' capacity to learn and make the most of their skills. 
In order for the creativity mechanism to be set in motion, the actor must experience dissatisfaction and be permanently driven by a strong desire to perform better. This leads to a higher, complex motivation which results in particularly personal, innovative ideas (Roşca, 1981).

\section{Conclusion}

The research outcomes reflected positive correlations between the indicator being assessed and the artistic performances of the student actors.

This research provides arguments for the idea that improvisation brings out some important elements regarding the talent of actors. The most relevant aspect in this respect relates to the fact that when dealing with highly difficult improvisation tasks, the ability to invent and the capacity of expression are directly connected to the artistic performance.

Analysing the creative capacity of the student actors based on improvisation underlines their different performance level both in terms of imagination and of expressiveness. This research also reveals the relationships between imagination and expressiveness in terms of unity, of the prevalence of one of these capacities and of the comprehension of the artistic message (Schofield \& Start, 2019). Therefore, the research enables us to prove also the hypothesis according to which the capacity for imagination and the capacity of expression are the defining components of creativity.

In point of the hypothesis we ground our research on, we can affirm that the relationship between imagination and scenic expression is the fruit of the correlation between the mental elaboration of the artistic behaviour and the expressive communication of the elaborated message. The intended meaning must be clearly and suggestively conveyed. The talent of an actor lies primarily in their creative imagination which is the prerequisite for the expressive projection of their emotional experiences. Besides being a training method, directed improvisation is a means to reveal the student actors' abilities and implicitly their scenic talent.

Performance art consists of the participation of the actors with their full personality. The internal resources of each participant drive, stimulate and inspire the performance, the actors having, without doubt, the reasons and the desire to generate a quality artistic product. This determines a specific attitude of the performer, which is the result of numerous rehearsals (Craig, 2012).

The research reflects two specific aspects of the imagination-expressiveness relationship, namely:

- There is unity between imagination and expressiveness which can be observed particularly in the student actors who score highest and in those who score lowest on the proposed situational test.

- There is a relative prevalence of one of the two indicators in the students with average artistic performances.

The analysis of the artistic achievements of the student actors generates two 
situations:

- Students with average imagination yet with a good to high capacity of expression are likely to imitate. We admit that in some cases they did a pretty good job. However, we also noticed their tendency to explicitly describe the improvisation topics. This could be considered a result of the low imagination level or of the low capacity for imagination as in a poor ability to invent.

- Students with average capacity of expression yet more imaginative tend to resort to easy solutions, to stereotypes. This could be due to poor coordination of the expression means.

In both cases, the student actors fail to communicate the improvised topic in a clear, full or accurate manner. Significant discrepancy in conveying the intended message in any of the aforementioned situations indicates a deficit in the psychological structure of the scenic talent. This can be partially redressed by training sessions aimed at developing the organic unity between the capacity for imagination and the capacity of expression (Barba \& Savarese, 1991).

We provide below a few weaknesses of this research:

- The small number of evaluators leads to higher subjectivity in judgment. On the other hand, small evaluation teams are generally highly competent. Unfortunately, we couldn't hire a larger team, due to lack of funds.

- Although in Romania all teachers must complete the teacher training module in order to work in the education area, the emphasis is placed on the teaching specialty they wish to pursue. In this context, the teachers specialised in the artistic field are partially qualified in the psychology area. The fact that the jury consists of two permanent teachers and only one psychologist suggests that the assessment reflects the artistic component in the evolution of the subjects to a larger extent than the psychological one.

- The small number of the tested students shows us that this research is rather a case study covering the class of students in question. Therefore we cannot generalise the results to the entire artistic education area. This would be feasible if the research was conducted on several classes of students and the results were compared to similar ones recorded by renowned actors.

Determining the relationship between the scenic talent indicators as well as the tasks that help build the talent applies both in performance art practice and in psychological research and it is a difficult task from a methodical standpoint. This research can be regarded solely as an attempt in this direction.

The assessment techniques relying on experimentally unverified rating scales, enable, however, the evaluators to assess the expressions based on observing the students perform and on their verbalisation of their intentions after they complete their task. As it is a method that provides information on the student actors' expressiveness level which could be correlated with data recorded on other types of tests (personality tests, IQ tests, and the like), thus enabling us to outline the subjects' psychological profile, we believe that it is an area worth looking into. This is an important aspect for it could lead to finding also prognostic not 
only diagnostic methods which might help both students and teachers in their career.

\section{Conflicts of Interest}

The author declares no conflicts of interest regarding the publication of this paper.

\section{References}

Aron, G. (1999). Improvizaţia jocului, jocul improvizaţiei. București: Editura Ecologică.

Barba, E., \& Savarese, N. (1991). A Dictionary of Theatre Anthropology: The Secret Art of the Performer. London: Routledge.

Botezatu, G., \& Hîncu, A. (2001). Dicționar de proverbe şi zicători româneşti. Chişinău: Editura Lira.

Craig, E. G. (2012). Despre Arta Teatrului. Bucureşti: Fundaţia culturală Camil Petrescu, Cheiron.

Golu, M. (2007). Fundamentele psihologiei, ediția a V-a, Vol. II. București: Editura Fundației România de Mâine.

Grotowski, J. (2009). Spre un teatru sărac. Bucureşti: Fundația culturală Camil Petrescu, Cheiron.

Iorga, A. (2017). Emotional Experiences of the Student Actor Identifying Simple and Complex Emotional Expressions. The European Proceedings of Social \& Behavioural Sciences, Vol. XX, Future Academy, UK, 102-110.

Morgenroth, J. (1987). Dance Improvisations. Pittsburgh: University of Pittsburgh Press.

Neacşu, G. (1971). Transpunere şi expresivitate scenic. Bucureşti: Editura Academiei.

Popescu, G. (2004). Psihologia creativității. Bucureşti: Editura Fundației România de Mâine.

Reeve, J. (2011). Dance Improvisations. Warm-Ups, Games and Choreographic Tasks. Leeds: Human Kinetics.

Roşca, A. (1981). Creativitatea generală şi specifică. Bucureşti: Editura Academiei,.

Schofield, C., \& Start, L. (2019). Psychology for Dancers-Theory and Practice to Fulfil Your Potential. London: Routledge.

Stanislavski, K. S. (2018). Munca actorului cu sine însuşi. Bucureşti: Editura Nemira.

Toivane, T., \& Kaasinen, M. (2016). Developing Drama Teachers' Body Awareness and Holistic Interactions Using Theatre Based Methods. The European Proceedings of Social \& Behavioural Sciences, ICEEPSY, Future Academy, UK, 122-131.

Zlate, M. (1999). Psihologia Mecanismelor Cognitive. Iaşi: Editura Polirom.

Zlate, M. (2000). Introducere în psihologie. Iaşi: Editura Polirom. 